\title{
The Curative Activity of Isolated Fraction from Spathodea campanulata Beauv Stem Bark on Rat's Exposed to Benzopyrene
}

\author{
Masruri Masruri $i^{1^{*}}$, Mohamad Lutfillah $^{1,2}$, Ady Sumaryanto $^{1}$, Rurini Retnowati ${ }^{1}$, Aulanni'am Aulanni' ${ }^{1}{ }^{1,3}$ \\ ${ }^{1}$ Department of Chemistry, Faculty of Mathematics and Natural Sciences, University of Brawijaya, Indonesia \\ ${ }^{2}$ School of Chemical Analysis, Department of National Education and Culture, Pasuruan, Indonesia \\ ${ }^{3}$ Veteriner Faculty, University of Brawijaya, Indonesia
}

\begin{abstract}
This paper reports a screening results of the secondary metabolites composed in Spathodea campanulata Beauv stem bark, evaluate inhibiting activity of malondialdehyde (MDA) on rat's cancer model exposed with benzopyrene, and the histology of its lung. The secondary metabolite of the stem bark fraction consisted of alkaloids, flavonoids-phenolic, terpenoid and steroid compounds. The isolated fraction contained of these metabolites significantly indicate bioactivity by reducting of malondialdehyde (MDA) level, and also histology appearance of the lung tissue prepared from the benzopyrene-exposed rat indicated a curative activity.
\end{abstract}

Keywords: angsret, malondialdehyde, mda, natural product, secondary metabolite, Spathodea campanulata

\section{INTRODUCTION}

Lung cancer has been much attention as its increasing prevalence globally. It has caused mortality and morbidity both on man and woman $[1,2]$. Smoking was reported gave about $80 \%$ contributions [3-5]. The tobacco smoke content such as benzo[a]pyrene [6] and other aromatic or poly-aromatics from a cigarette burning products which were able to cause lung cancer including squamous-cell carcinoma, small-cell carcinoma, adenocarcinoma (including bronchiolar or alveolar carcinoma) and large cell carcinoma [5].

The on going research in order to explore the potency of Indonesian indigeneous plant has focused on S. campanulata Beauv (family Bignonaceae) [7]. Found as a high plant with orange flower habitat for some rare bird species in Merubetiri National Conservation area, South Banyuwangi forest [8]. The local name is angsret (East Java), kiengsrot (Aceh), kayu perahu (Kalimantan), sepatu diat (Melayu), kacret-kacretan (Bali), Kiancret (Jakarta) and kecrutan (Malang). It has also widely been used for city garden plants, to build wood-boat, and part of its plants such as stem bark and aerial parts was reported as traditional medicine, antimalarial, antibacterial, anti inflammatory, and antiviral

${ }^{*}$ Corresponding author:

Masruri Masruri

Department of Chemistry, University of Brawijaya

Jl. Veteran, Malang, Indonesia, Tel./Fax. +62 341575858 / 554403

E-mail: masruri@ub.ac.id
[9-13, 15-17]. Recently, we found a non-polar fraction of stem bark contained triterpenoids compounds strongly inhibit bacterial growth and this paper is disclosed a malondialdehyde level reduction and curative activity of stem bark's extract fraction on a rat exposed with benzo[a]pyrene, and also the histology of lung tissue $[14,18]$.

\section{MATERIALS AND METHODS \\ Chemicals}

All chemicals used has analytical reagent grade (or as mentioned); ethanol (Bratachem), ethyl acetate (Bratachem) and n-hexane (Bratachem) was applied after purification and drying process following standard purification and drying methods for organic solvent. Mercury chloride (Merck), potassium iodide (Merck), iodine (Sigma), hydrochloric acid (Smart Lab), sulphuric acid (Smart Lab), bismuth nitrate (Sigma), magnesium powder (Sigma), and iron(III) chloride (Smart Lab). A malondialdehyde test kit, and a kit for histology observation.

\section{Plants sample preparation}

The plant sample was collected from Brawijaya University garden and identified by drs. Djati Batoro in the Laboratory of Taxonomy, University of Brawijaya. Amounts $3.0 \mathrm{~kg}$ of air-dried and grinded stem bark was macerated with methanol $(\mathrm{FMeOH})$. The isolate fraction of ethyl acetate (FEA) and n-hexane ( $\mathrm{FnH})$ was 
afforded from partition of methanol extract after solvent evaporation. Then, each isolate fraction was stored in freezer before application.

\section{Procedure for secondary metabolite evaluation}

The presence alkaloid was clarified using Meyer reagent, Dragendorf reagent, and Wagner test. Mayer test: Extract methanol of stem bark $(1 \mathrm{~mL})$ was added a Mayer reagent (mixture of solution $1.3 \mathrm{~g}$ of mercury (II) chloride in $50 \mathrm{~mL}$ aquadest and solution of $5 \mathrm{~g}$ potassium iodide in $50 \mathrm{~mL}$ aquadest). A white precipitate is indicated as an alkaloid. Dragendorf test: Methanol extract of stem bark $(1 \mathrm{~mL})$ was added a few drop of concentrated hydrochloric or sulphuric acid, and Dragendrof reagent (a mixture of solution potassium iodide $8 \mathrm{~g}$ in $20 \mathrm{~mL}$ aquades and solution bismuth nitrate $1 \mathrm{~g}$ in $50 \mathrm{~mL}$ aquades). The presence of alkaloid was indicated as orange precipitation. Wagner test: Methanol extract of stem bark $(1 \mathrm{~mL})$ was added Wagner reagent (a mixture of iodide $1.5 \mathrm{~g}$ and $2 \mathrm{~g}$ potassium iodide in $10 \mathrm{~mL}$ aquades). Positive test for alkaloid was indicated as brown precipitate.

Flavonoid test was undertaken using Shinoda test conducted by addition of ethanol $(5 \mathrm{~mL})$ to the sample $(100 \mathrm{mg}$ ), and then it was added magnesium powder and a few drop of concentrated hydrochloric acid. The presence of flavonoid indicated color as orange (flavonoid), red (flavonol), and purple (xanthone). Flavonoid could react with sulphuric acid to give a dark yellow or red-blue (chalcone, aurone), orange-red (flavonone).

Phenolic compounds were tested using air dry stem bark $(100 \mathrm{mg})$, and extracted with methanol. The resulted extract was added solution iron (III) chloride $1 \%$. The presence of phenolic compound was indicated when the solution turn to violet or green-black.

Terpenoid and steroid test was conducted according to Lieberman-Burchard test and Salkowski test [20, 21]. The Lieberman-Burchard test was performed by addition of sample $(2 \mathrm{~mL})$ with a few drops of concentrated sulphuric acid and acetic anhydride. The presence of terpenoid was indicated with color blue, red and violet. Salkowski test was perfomed by addition of methanol extract sample $(2 \mathrm{~mL})$ with chloroform (1 $\mathrm{mL})$, and concentrated sulphuric acid $(1 \mathrm{~mL})$ [21]. The presence of red or orange indicated terpeneoid steroid compounds.

\section{Animal treatment}

The standard procedure was conducted using animal as research model has met the ethical clearance procedure in Brawijaya University. The prepared animal with pre-cancer was conducted according to [22]. The Rattus novergicus rat species was divided into 5 groups: first group consists of healthy mice as control, and second group contained mice exposed with benzopyerene and groups three to five composed mice-exposed benzopyrene with different treatments using isolate fraction of $\mathrm{n}$-hexane $(\mathrm{FnH})$, ethyl acetate (FEA), and methanol $(\mathrm{FMeOH})$. For groups of benzopyereneexposed mice were injected intraperitoneally with benzopyrene solution ( $1.0 \mathrm{~g}$ benzopyrene dissolved in 5.0 $\mathrm{mL}$ of corn oils) using doses $200 \mathrm{mg} / \mathrm{kg}$ of body weight. The injection was repeated 4 times and incubated for 30 days after the last injection [23]. After the incubation time, three groups of mice exposed benzopyrene were treated with $\mathrm{FnH}, \mathrm{FEA}$, and $\mathrm{FMeOH}$. Sample of FnH and FEA was prepared by dissolving in corn oils $(200 \mu \mathrm{L})$ and aquadest $(1800 \mu \mathrm{L})$, while for $\mathrm{FMeOH}$ was dissolved in aquadest $(2.0 \mathrm{~mL})$. The injection of each group was performed 7-times (doses 100 $\mathrm{mg} / \mathrm{kg}$ of body weight) for 7 day and incubated for 30 days. Then, mice were sacrificed and the lung was prepared for histology using haematoxylene-eosin (HE) method and malondialdehyde (MDA) analysis.

\section{Malondialdehyde standard curve}

A kit of malondialdehyde with variation concentration $(0 ; 1.0 ; 2.0 ; 3.0 ; 4.0 ; 5.0 ; 6.0 ; 7.0$; and $8.0 \mu \mathrm{g} / \mathrm{mL})$ was pippetted $(100 \mu \mathrm{L})$ in reaction tube and each was dissolved with aquadest $(550 \mu \mathrm{L})$. Each of tube was added standard trichloroacetic acetic $(100 \mu \mathrm{L}, 100 \%)$, hydrochloric acid $(250 \mu \mathrm{L}, 1.0 \mathrm{M})$, and sodium thiobarbiturate $(100 \mu \mathrm{L}, 1.0 \%)$. The homogenized of these solutions were centrifuged at $500 \mathrm{rpm}$ for $10 \mathrm{~min}$, wrapped with plastic, and incubated in waterbath $\left(100^{\circ} \mathrm{C}\right)$ for $30 \mathrm{~min}$. After cold at room temperature the samples were taken for quantitative MDA analysis using spectrophotometer $(\lambda \max 533 \mathrm{~nm})$.

\section{Malondialdehyde measurement}

The homogenized mixture of lung tissue $(0.45 \mathrm{~g})$ and a cold sodium chloride solution $(1.0 \mathrm{~mL}, 1.0 \%)$ was centrifuged at $8000 \mathrm{rpm}$ for $20 \mathrm{~min}$ to afford supernatant. A $100 \mu \mathrm{L}$ of this supernatant in reaction tube was added aquadest $(550 \mu \mathrm{L})$, trichloroacetic acid, TCA $(100 \mu \mathrm{L}, 10 \%)$ and was further homogenized. This mixture was added hydrochloric acid $(250 \mu \mathrm{L}, 1.0$ $\mathrm{M})$, sodium thiobarbiturate $(250 \mu \mathrm{L})$ and re-homogenized, centrifuged at $500 \mathrm{rpm}$ for $10 \mathrm{~min}$ to result supernatant. The resulted supernatant was incubated in waterbath $\left(100^{\circ} \mathrm{C}\right)$ for $30 \mathrm{~min}$, further centrifuged to 
afford supernatant, and prepared for analysis using spectrophotometer $(\lambda \max 533 \mathrm{~nm})$. The absorbance resulted was plotted in malondialdehyde curve standard to calculate the concentration.

\section{RESULTS AND DISCUSSION}

Phytochemical analysis of $S$. campanulata Beauv stem bark using secondary metabolite's visualization reagent indicated a diverse group of compound composed the stem bark. The hexane fraction contained phenolic, steroid and terpenoid compounds. Meanwhile for both ethyl acetate and methanol fraction was composed with similar class of secondary metabolite such as alkaloid, flavonoid, phenolic, saponin, steroid, and terpenoid (Figure $1 \mathrm{~A}$ ). equilibrium quantity for normal cell $[24,25]$. This level up of ROS can promote cell mutation, DNA mutation, and lead on the failure of cell differentiation or cancer inititation [26]. Conversely, the inhibition of ROS concentration in cell can be expressed with the reduction of the MDA in cell [27-29].

The result gave positive affect that all of the isolate fractions reduced the MDA concentration on the rat's model which was exposed using benzopyerene (BP). The highest lowerring MDA concentration when it was treated using hexane isolate fraction $(\mathrm{FnH})$. The MDA value reduced to $0.3408 \mu \mathrm{g} / \mathrm{mL}$ (or decreased by $50 \%$ ). In similar word, this fraction was able to inhibit more than $50 \%$ reactive oxygen species in cell [27-29]. While for isolate fraction from ethyl acetate (EA) and

\begin{tabular}{lcccccc}
\hline \multirow{2}{*}{ Fractions } & \multicolumn{6}{c}{ Phytochemical Test } \\
\cline { 2 - 7 } & Alkaloid & Flavonoid & phenolics & Saponin & Steroid & Terpenoid \\
\hline n-Hexane & - & - & + & - & + & + \\
Ethyl acetate & + & + & + & + & + & + \\
Methanol & + & + & + & + & + & + \\
\hline
\end{tabular}

A

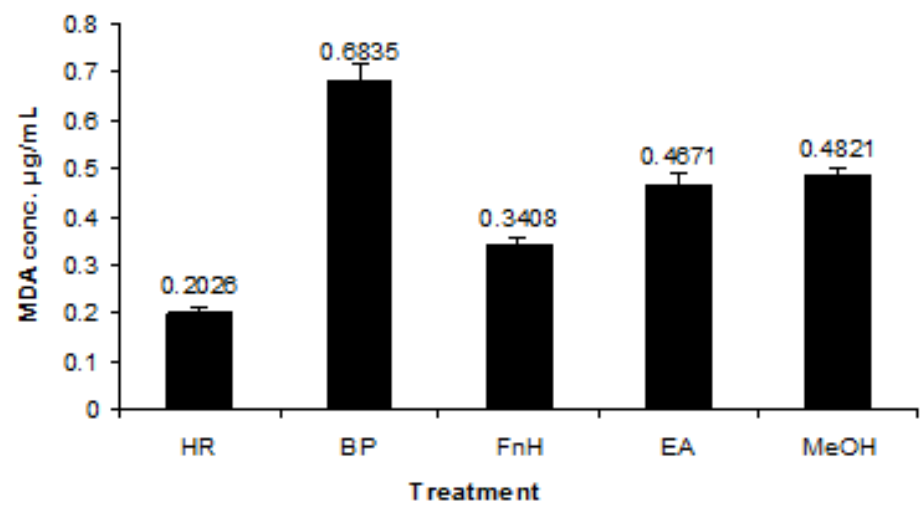

B

Figure 1. A. Phytochemical screening of $S$. campanulata Beauv stem bark. B. MDA concentration of the healthy rat (HR), rat exposed benzopyerene (BP), rat with treatment using $\mathrm{FnH}$ (rat exposed benzopyrene treated with hexane fraction), EA (rat exposed benzopyrene treated with ethyl acetate fraction), and $\mathrm{MeOH}$ (rate exposed benzopyrene treated with methanol fraction).

Semi-clinical evaluation using rat's model for cancer by exposing it with benzopyrene gave a significant feature. Increasing MDA concentration in cell as normal or healthy rat $(0.2026 \mu \mathrm{g} / \mathrm{mL})$ to 0.6835 $\mu \mathrm{g} / \mathrm{mL}$ as important indication the affect of benzopyrene on cell (Figure $1 \mathrm{~B}$ ). This was also a signal increasing the number of reactive oxygen species (ROS) in cell where ROS in cell such as peroxide, hydroxyl radical, and radical oxygen group presence at methanol $(\mathrm{MeOH})$ was able to inhibit about $30 \%$ of ROS. Comparing to the healthy rat (MDA concentration was $0.2026 \mu \mathrm{g} / \mathrm{mL}$ ), the isolate fraction from hexane significantly has a close value on it. This isolate fraction basically could heal the sick cell on lung tissue. Further observation toward curative activity on lung tissue was undertaken using histology observation. The result is presented in Figure 2 and 3. 


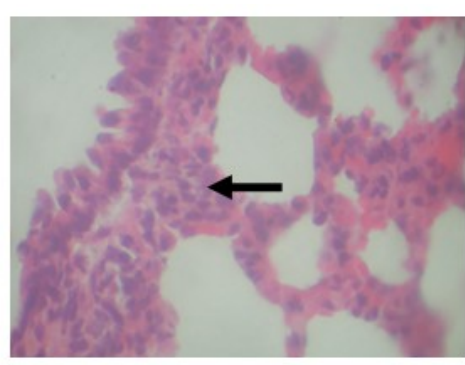

A

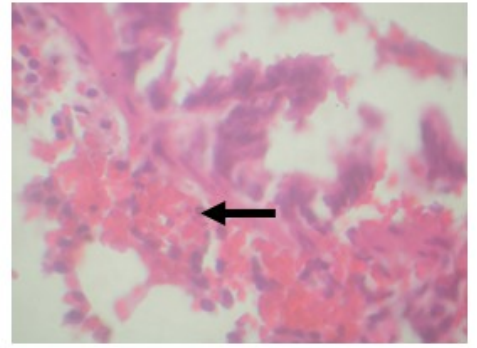

B

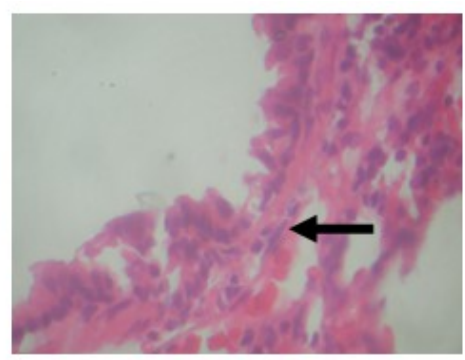

E

C

D

Figure 2. A. Hystology of rat's lung. Healty rat as a negative control. B..Sick rat which was exposed with benzopyrene $200 \mathrm{mg} / \mathrm{Kg}$ of body weight...Hystology of lung's rat exposed with benzopyerene after treatment with isolate fraction of $S$. campanulata stem bark. C. FnH, n-hexane, D. FEA, ethyl acetate, E. FMeOH, methanol.

The affect an intraperitoneal injection of benzopyrene on rat histologicaly could damage cell in lung tissue [23]. Figure 2 B displays its histology result. Cell disintegration and covered by yellow block due to cell mutation, differentiation, and cancer was observed. This consistent with previous result that benzopyrene could increase ROS quantity in cell. This increase can damage the cell itself, and also the MDA concentration in cell going up. While in the lung tissue of healthy rat which was not exposed with benzopyrene indicates a solid cell, no disintegration and differentiation was observed (Figure $2 \mathrm{~A}$ ).

Oral treatments with isolate fractions prepared (dose $100 \mathrm{mg}$ per kilogram of rat's body weight) was undertaken using some groups of sick rat exposed with benzopyrene, and these were following by incubation for 30 day. The histology result of lung tissue as display in figure 2. All of the isolate fractions provide better a cell solidity compare to cell of sick rat (Figure 2 B). This result reveals that all of the isolate fractions were able to cure the damage, injured, or disintegrated of cell.

The best visual observation was on that was treated using hexane's isolate fraction. It seemed disintegration of cell was not occured. Cell completely solid, no hole inside cell was observed, and appeared similar to the healthy cell as it in Figure $2 \mathrm{~A}$. With this result, it is believed that compound composed hexane's isolated fraction responsible in restoring the damage cell. The phenolic, steroid and terpenoid compounds of secondary metabolite possibly able to cure the cell disintegration. Even though the mechanism undergone was not clear yet, it is believed correlate to inhibition during the formation of reactive oxygen species (ROS) by reducing MDA concentration.

\section{CONCLUSIONS}

The curative activity of $S$. campanulata Beauv stem bark isolate fraction on rat's model for lung cancer was found. It was oberserved as reduction activity of MDA concentration on cell, and its histology appearance of lung's tissue. Moreover, some important groups of secondary metabolite responsible isolated for this was phenolic, steroid, and terpenoid compounds.

\section{ACKNOWLEDGMENT}

This research was funded from National Research Competition Grants (Penelitian Hibah Bersaing) from Directorate General of Higher Education of Republic Indonesia.

\section{REFERENCES}

1. Siegel R, Naishadham D, Jemal A (2013) Cancer statistics. CA: A Cancer Journal for Clinicians. 63(1): 11-30. 
2. Ahmedin JFB, Melissa MC, Ferlay J, Ward E, Forman D (2011) Global Cancer Statistics. CA: A Cancer Journal for Clinicians. 61(2): 69-90.

3. Ezzati M, Lopez AD (2004) Regional, disease specific patterns of smoking-attributable mortality in 2000 . Tobacco Control. 13(4): 388-395.

4. Pelucchi C, Gallus S, Garavello W, Bosetti C, Vecchia CL (2006) Cancer Risk Associated with Alcohol and Tobacco Use: Focus on Upper Aerodigestive Tract and Liver. Health Risks. 29(3): 193-198.

5. Hecht SS (2003) Tobacco Carcinogens, Their Biomarkers and Tobacco-Induced Cancer. Nature Reviews. 3: 733-744.

6. Phillips DH (1983) Fifty years of benzo[a]pyrene. Nature (London, United Kingdom). 303: 468-472.

7. Gilman EF, Watson DG (1994) Spathodea campanulata African Tulip Tree, Fact Sheet ST-600, a series of the Enviromental Holticulture Department. In Florida Cooperative Extension Service, Institute of Food and Agricultural Science, University of Florida. Gainesville.

8. Parikesit, Takeuchi K, Tsunekawa A, Abdoellah OS (2004) Kebon tatangkalan: a disappearing agroforest in the Upper Citarum Watershed, West Java, Indonesia. Agroforestry Systems. 63: 171-182.

9. Gem (2004) Peringatan Hari Bumi Menjaga Hidup Berlanjut di Bumi. In Kompas, Kompas Media. Jakarta.

10. Aprianti Y, Pasupati (2005) Jembatan Kecapi Suling Orang Sunda. In Kompas, Kompas Media. Jakarta.

11. Corner EJH (1997) Wayside Trees of Malaya. 4th ed.; Malayan Nature Society: Malaysia. Vol. 1B.

12. Amusan OOG, Adesogan EK, Makinde JM (1996) Antimalarial Principles of Spathodea campanulata Stem Bark. Phytotherapy Research. 10(8): 692-693.

13. Masruri, Soebiantoro (2007) Uji Aktivitas Antimikroba Fraksi Non-Polar Ekstrak Bunga dan Kulit Batang Tanaman Spathodea campanulata Beauv. Jurusan Kimia. Universitas Brawijaya. Malang.

14. Masruri, Soebiantoro, Retnowati R (2008) Karakterisasi Senyawa Triterpenoid dari Kulit Batang Tanaman Angsret, Spathodea campanulata P. BEAUV (BIGNONACEAE). Natural. 12(1): 22-31.

15. Widyasari AR (2008) Karakterisasi dan Uji Antibakteri Senyawa Kimia Fraksi n-Heksana dari Kulit Batang Pohon Angsret (Spathodea campanulata Beauv.). Skripsi, University of Brawijaya. Malang.

16. Olugbade TA (2005) Natural Options for The Development of Pharmaceutical Industries in Nigeria. Obafemi Awolowo University Press Limited: Ile-Ife. Nigeria.

17. Hudson JB, Anail K, Souzal C, Akpaganal K, Tower GHN, Amason JT, Gbeassor M (2000) Investigation of Medicinal Plants of Togo for Antiviral and Antimicrobial Activities. Pharmaceutical Biology. 38(1): 40-45.
18. Kusnaeni V (2008) Isolasi dan Karakterisasi Senyawa Fraksi n-Heksana dari Ekstrak Kulit Batang Angsret (Spathodea campanulata Beauv.). Skripsi (Undergraduate Thesis). Jurusan Kimia, Fakultas MIPA, Universitas Brawijaya. Malang.

19. Verma A, Laakso I, Seppänen-Laakso T, Huhtikangas A, Riekkola ML (2007) A Simplified Procedure for Indole Alkaloid Extraction from Catharanthus roseus Combined with a Semi-synthetic Production Process for Vinblastine. Molecule. 12: 1307-1315.

20. Jagesar RC, Cox M (2010) Phytochemical screening of the chloroform and ethanol extract of stems, twigs, root and bark of Conocarpus erectus L. International Journal of Academic Research. 2(5): 37-45.

21. Egwaikhide PA, Gimba CE (2007) Analysis of phytochemical content and antimycrobial activity of Plectranthus glandulosis whole plants. Middle East Journal of Scientific Research. 2(2-4): 135-138.

22. Nakamura K, Yamaguchi Y, Kagota S, Kwon YM, Shinozuka K, Kunimoto M (1999) Inhibitory effect of Cordyceps sinensis on spontaneous liver metastasis of lewis lung carcinoma and B16 melanoma cells in syngenic mice. The Japan Journal of Pharmacology. 79(3): 335-341.

23. Jones K (2012) Intraperitoneal (IP) Injection in Rats and Mice SOP. University of British Columbia.

24. Asha S, Girija D (2011) Benzo[a]pyrene induced liver and kidney cancer in swiss albino mice. Research in Pharmacy. 1(4): 22-27.

25. Aoki $\mathrm{Y}$, Hashimoto $\mathrm{AH}$, Amanuma K, Matsumoto M, Hiyoshi K, Takano H, Masumura K, Itoh K, Nohmi T, Yamamoto M (2007) Enhanced Spontaneous and Benzo(a)pyrene-Induced Mutations in the Lung of Nrf2Deficient gpt Delta Mice. Cancer Research. 67 (12): 56435648.

26. Waris G, Ahsan H (2006) Reactive oxygen species: role in the development of cancer and various chronic conditions. Journal of Carcinogenesis. 5(14): 1-8.

27. Richard SLP, Tomandl J, Kaňková K, Tóthová E, Gál B, Kostřica R, Salzman P (2009) Elevated Malondialdehyde Correlates with the Extent of Primary Tumor and Predicts Poor Prognosis of Oropharyngeal Cancer. Anticancer Research. 29: 4227-4232.

28. Gadjeva V, Kucthukova D, Aladjov E, Georgieva R (2005) Correlation Between Plasma Malondialdehyde and Ceruloplasmin Activity in Patients with Malignant Haematological Diseases. Trakia Journal of Sciences. 3(2): 29-33.

29. Aashita Gupta MLB, Mithilesh KM (2009) Lipid peroxidation and antioxidant status in head and neck squamous cell carcinoma patients. Oxidative Medicine and Cellular Longevity. 2(2): 68-72. 